\title{
Analysis of Pancasila Values on Narrative Composition Material in Primary Schools
}

\author{
Ratih Asmarani \\ Faculty of Education \\ State University of Malang, Indonesia \\ ratihasmrn@gmail.com
}

\author{
Murtiningsih \\ Faculty of Education \\ State University of Malang, Indonesia \\ murtiningsih.fip@um.ac.id
}

\author{
Imam Nawawi \\ Faculty of Education \\ State University of Malang, Indonesia \\ imam.nawawi.fip@um.ac.id
}

\begin{abstract}
Intention of this research, that is to know: (1) the infinite value in composition of narasi student; (2) human value in composition of narasi student; (3) association value in composition of narasi student; (4) nationality value in composition of narasi student; and (5) justice value in composition of narasi student. Data obtained from tes compose composition of narasi interview and. This research conclude that class student 4 in SDN Pandanwangi 3 Malang from 35 student have shown 233 five principles value which included in composition of narasi which have made of.
\end{abstract}

Keywords: value five principles, composition of narasi

\section{INTRODUCTION}

Education represent important matter which must have by each; every human being, even education have started to be inculcated by old fellow since in content. Education is the effort and conciousness of planned to realize atmosphere learn and study process so that/to be educative participant actively develop self potency to have the power of religious spiritual, self control, personality, intellegence, august behavior, and also needed by skill is self, society, state and nation.

Development of self potency can be maximized to pass/through education when someone have started to go through formal education bench, education of national is to education which pursuant to Five Principles and Constitution State Republic of Indonesia Year 1945 taking root at religion values, culture of Indonesia national and listen carefully to demand change of epoch.

Value Five Principles represent a hand in glove value of its bearing with everyday life. Five Principles alone represent Indonesian nation ideology, namely about meaning live and values determining flat flatly how human being have to live and act. Indonesian represent one of the payload exist in elementary school with aim to to inculcate ability of educative participant in communicating verbally and also article better.

Narasi represent an reading narrating a event path, passing a composition of narasi made by is student as according to event which have been experienced of by student earn is also functioned to inculcate, and knowing assess Five Principles in a composition of narasi which have been written by student.

\section{METHOD}

This Research uses an approach qualitative. In this research of the researcher of explaining the result of research by using Ianguage and words by details as according to object to check to give a picture presentation of data. type of research this is descriptive qualitative, because this research aim to Five Principles values describes (assess the infinite, human, association, nationality, and justice) which is up at result of composition of naration class student 4 objectively in the form of words in SDN Pandanwangi 3 Kota Malang.

This research take class subjek 4 , with amount 35 student. Data which is researcher take away from this research namely composition of narasi of class student 4 SDN Pandanwangi 3 Unlucky Town. Technique data collecting which is used in this research that is: (1) interview, done/conducted with class teacher 4 SDN Pandanwangi 3 Kota Malang, (2) sheet compose, to be used as by place compose composition of naration, and (3) documentation, comprising photo activity of student make a composition of narasi, and result compose composition of narasi student.

Data which have been gathered in the form of result of composition article of narasi class student 4 in SDN Pandanwangi 3 Kota Malang will be analysed by using descriptive method namely explain $\mathrm{a}[\mathrm{n}$ problems or an situation as things have panned out. This clarification later will dipaparkan pass/through words having the character of is narrative. Data analysis in this research Pass/through three phase, that is: (1) data discount, reducing data mean to embrace, chosening fundamental things, focussed at the essentials, searched by theme and his/its pattern (Sugiyono, 2008:247). Activity at this phase cover seeking and perception to element aspect of ekstrinsik which related to five Five Principles values which there are in result of composition of narasi student in class 4 in SDN Pandanwangi 3 Kota Malang, (2) presentation of data, phase presentation of researcher data will do/conduct the following matter: (a) identify, to be[done/conducted by reading result of composition article of narasi student, and identify article which related to element aspect of ekstrinsik about five Five Principles value, (b) codification, gift/ giving of code to aspect assess Five Principles which is found in composition of 
narasi student which is its target to facilitate researcher in analysing, and (c) with drawal of conclusion, researcher conclude from result. Codification assess used as by Five Principles is guidance in analysing Five Principles value in composition of narasi the following student (Table 1, Table 2, Table 3). After categorized by amount and presentase apparition of value of principles researcher present data in a statement.

Table 1

Codification Value of Principles

\begin{tabular}{|c|c|c|c|c|}
\hline No & $\begin{array}{c}\text { Category Assess Five } \\
\text { Principles }\end{array}$ & Description & Indicator & Code \\
\hline 1. & Value Believing in god & $\begin{array}{l}\text { Value the infinite is value related to } \\
\text { confidence and fear of human being to } \\
\text { God Which is Single The most. }\end{array}$ & $\begin{array}{l}\text { Confidence of [is existence of God } \\
\text { Fear at God } \\
\text { Tolerance between people believe in } \\
\text { Freedom embrace and run religion }\end{array}$ & $\begin{array}{l}\text { KT } 1 \\
\text { KT } 2 \\
\text { KT } 3 \\
\text { KT } 4\end{array}$ \\
\hline 2. & Human Value & $\begin{array}{l}\text { Human value is value related to } \\
\text { treatment to life between human being }\end{array}$ & $\begin{array}{l}\text { Is loving each other fellow being } \\
\text { Developing tolerance attitude } \\
\text { Respecting and esteeming nation, faction, or state } \\
\text { Dare to advocate truth }\end{array}$ & $\begin{array}{l}\text { KM } 1 \\
\text { KM } 2 \\
\text { KM } 3 \\
\text { KM } 4\end{array}$ \\
\hline 3. & Value Association & $\begin{array}{l}\text { Association value is value related to } \\
\text { unity at nation, within reason Indonesia } \\
\text { state password namely Single Bhinneka } \\
\text { of Ika having a meaning of different } \\
\text { each other but remain to one also }\end{array}$ & $\begin{array}{l}\text { Fatherland love } \\
\text { Moving forward assocciation which is Single } \\
\text { Bhinneka ber of Ika } \\
\text { Volunteer hold the bag for the sake of with respect } \\
\text { unity and association }\end{array}$ & $\begin{array}{l}\text { P } 1 \\
\text { P } 2 \\
\text { P } 3\end{array}$ \\
\hline 4. & Value Nationality. & $\begin{array}{l}\text { Nationality value is value related to } \\
\text { democracy in Indonesia state with aim } \\
\text { to to move forward prosperity of } \\
\text { Indonesia }\end{array}$ & $\begin{array}{l}\text { Deliberation to reach general consensus in a condition } \\
\text { of by feeling familiarity } \\
\text { Do not force others will desire } \\
\text { Sovereignty reside in on-hand people } \\
\text { Majoring deliberation in taking decision for the sake } \\
\text { of with }\end{array}$ & $\begin{array}{l}\text { KR } 1 \\
\text { KR } 2 \\
\text { KR } 3 \\
\text { KR } 4\end{array}$ \\
\hline 5. & Value Justice & $\begin{array}{l}\text { Justice value is value related to balance } \\
\text { [among/between] rights } \\
\text { and obligation in life }\end{array}$ & $\begin{array}{l}\text { Behave fairly balancing among/between rights and } \\
\text { obligations } \\
\text { Familiarity attitude and mutual assistance } \\
\text { Always scrimp and is not extravagant }\end{array}$ & $\begin{array}{l}\text { KL } 1 \\
\text { KL } 2 \\
\text { KL } 3\end{array}$ \\
\hline
\end{tabular}

Table 2

Category of Presentase Diversity of Five Principles Value

\begin{tabular}{|c|l|c|c|}
\hline No & \multicolumn{1}{|c|}{ Persentage } & Sense & Information \\
\hline 1. & $60 \%-100 \%$ & SB & Very good \\
\hline 2. & $40 \%-59 \%$ & B & Good \\
\hline 3. & $20 \%-39 \%$ & C & Enough \\
\hline 4. & $0-19 \%$ & SK & Very less \\
\hline
\end{tabular}

Table 3

Category of is Amount of Apparition of Five Principles value

\begin{tabular}{|l|l|c|c|}
\hline No & \multicolumn{1}{|c|}{ Percentage } & Sense & Information \\
\hline 1. & 60 times -100 times & SB & Very much \\
\hline 2. & 40 times -59 times & B & Many \\
\hline 3. & 20 times- 39 times & C & Enough \\
\hline 4. & $0-19$ times & SK & Few \\
\hline
\end{tabular}

\section{RESULT AND DISCUSSION}

Research having taken steps to result of composition of narasi at 35 researcher student find most of all Five Principles value included in composition of narasi student. Assess the infinite found in 33 result of composition of narasi student, human value found in 32 result of composition of narasi student, assess association found in 33 result of composition of narasi student, assess nationality found in 13 result of composition of narasi student, and justice value found in 16 result of composition of narasi student.

Value the infinite with confidence indicator of is existence of God, found by 31 sentence in composition of narasi student. Assess the infinite with fear indicator at God, found by 31 sentence in composition of narasi student. Assess the infinite with tolerance indicator between people believe in, to be found by 7 sentence in composition of narasi student. Assess the infinite with freedom indicator embrace and run religion, found by 6 sentence in composition of narasi student. Human value with indicator is loving each other fellow being, found by
31 sentence in composition of narasi student. Human value with indicator develop tolerance attitude, found by 4 sentence in composition of narasi student. Human value with indicator respect and esteem nation, faction, or state, found by 1 sentence in composition of narasi student.

Association value with indicator love fatherland, found by 3 sentence in composition of narasi student. Assess association with indicator move forward assocciation which is Single Bhinneka ber of Ika, found by 15 sentence in composition of narasi student. Assess association with indicator volunteer hold the bag for the sake of with, found 28 sentence in composition of narasi student. Assess association with indicator respect unity and association, found by 10 sentence in composition of narasi student.

Nationality value with deliberation indicator to reach general consensus in a condition of by feeling familiarity, found by 13 sentence in composition of narasi student. Assess nationality with indicator major deliberation in taking decision for the sake of with, found 13 sentence in composition of narasi student. Justice value with indicator behave fairly, found by 2 sentence in composition of narasi student. Assess justice with indicator balance among/between rights and obligations, found by 6 sentence in composition of narasi student. Assess justice with familiarity attitude indicator and mutual assistance, found by 8 sentence in composition of narasi student.

Pursuant to data presentation above, there are some Five Principles value which do not emerge in composition of narasi student. Some Five Principles value, that is: (1) human value, with indicator dare to advocate truth (KM 4); (2) nationality value, with indicator do not force others will desire (KR 2) and sovereignty reside in on-hand people (KR 3); and (3) justice value, with indicator always scrimp and is not extravagant (KL 4). There are 5 
value which there are in Five Principles value, that is: (1) the infinite value, (2) human value, (3) association value, (4) nationality value, and (5) association value (Wahidin, 2016). Pursuant to data presentation and research finding result, hence can be compiled by solution of the following research.

\section{Value Believing in God}

Value the infinite found in 34 composition article of narasi student. Assess the infinite with confidence indicator of [is existence of God found in 33 sentence found on 31 result of composition of narasi student. Assess the infinite with fear indicator at God found in 33 sentence found on 31 result of composition of narasi student. Assess the infinite with tolerance indicator between people believe in to be found in 7 sentence found on 7 result of composition of narasi student. Assess the infinite with freedom indicator embrace and run religion found in 6 sentence found on 6 result of composition of narasi student.

As a whole at the infinite value found by counted 34 composition of narasi student which in it emerge 79 sentence which enter in plenty of category with percentage $34 \%$ expressing last for meaning related to the infinite value. Following solution of analysis assess the infinite. Composition article of narasi student with code of A1, A2, A3, A4, A6, A7, A8, A9, A10, B1, B2, B4, B6, B7, B8, B9, B10, C1, C2, C2, C3, C4, C5, C6, C7, $\mathrm{C} 8, \mathrm{C} 9, \mathrm{C} 10, \mathrm{D} 1, \mathrm{D} 2, \mathrm{D} 3, \mathrm{D} 4, \mathrm{D} 5$, and D6 there are the infinite value, because at sentences with the student code write down word pray, studying to have, religious service, and tolerance between people believe in the.

The word show or meaningful that all activity which is mentioned in composition of narasi the student relate to the existence of God and things which is flange at religion activity as according to first principle of Five Principles. This matter as according to content of [is meaning of the infinite value namely confession and confidence of nation to existence of God as creator of universe, and also confession of freedom will to embrace religion, respecting independence believe in, there no not applicable constraint and also diskriminatif between people believe in, and also assess the infinite relate at confidence to God and life by running His comand without bothering other religion business (Meinarno, 2016).

Pursuant to solution above, result of composition of narasi student concerning the infinite value with indicator: (1) confidence of is existence of God, (2) fear at God, (3) tolerance between people believe in, and (4) freedom embrace and run religion, have emerged in composition of narasi student. This matter is influenced by student routinely have done/conducted activity related to is fourth of indicator. The activitys besides routine done/conducted by in possibility school is also done/conducted at home, and also in society, taking example, berjamaah sholat with, praying before and after learning, respecting difference of religion, because in class 4 do not only consisting of one just religion, student so that earn is esteeming each other difference of religion and inculcate attitude of tolerasi of the mentioned.

\section{Human Value}

Human value found in 33 composition article of narasi student. Human value with indicator is loving each other fellow being found in 41 sentence found on 31 result of composition of narasi student. Human value with indicator develop tolerance attitude found in 4 sentence found on 4 result of composition of narasi student. Human value with indicator respect and esteem nation, faction, or state found in 1 sentence found on 1 result of composition of narasi student.

As a whole at human value found by counted 33 composition of narasi student which in it emerge 46 sentence which enter in category many with percentage $20 \%$ expressing last for meaning related to human value. Following solution of human value analysis. Composition article of narasi student with code of A1, A2, A3, A4, A5, A6, A7, A9, A10, B1, B2, B3, B4, B6, B7, B8, B9, B10, $\mathrm{C} 1, \mathrm{C} 2, \mathrm{C} 3, \mathrm{C} 4, \mathrm{C} 5, \mathrm{C} 6, \mathrm{C} 7, \mathrm{C} 8, \mathrm{C} 9, \mathrm{C} 10, \mathrm{D} 1, \mathrm{D} 3, \mathrm{D} 4$, D5, and D6 there are human value, because at sentencesentence with the student code write down word each other helping each other, is assisting each other, care to humanity, and is esteeming each other and respecting other human being. The word show or meaningful that all activity which is mentioned in composition of narasi the student relate to human relation/link among/between human being one with other human being and as according to second principle of Five Principles.

This matter as according to content of is meaning of meaningful human value of awareness of behavior and attitude as according to moral values in life with on the basis of conscience demand by treating something matter properly, and this is human value more emphasizing at to treat individual to other society or individual, hence from that claimed also the existence of fair attitude in treating others, without seeing tribe, race, and or other difference which owned by per head (Meinarno, 2016).

Pursuant to solution above, result of composition of narasi student concerning human value with indicator: (1) is loving each other fellow being, (2) developing tolerance attitude, and (3) respecting and esteeming nation, faction, or state, have emerged in composition of narasi student. This matter is influenced by student routinely have done/conducted activity related to third indicator. The activitys besides routine done/conducted by in possibility school is also done/conducted at home, and also in society, taking example, helping or assisting one who is difficulty and require help, esteeming and respecting to each;every human being start from more young, humanity, and also is older, obedient and obey to one who is older.

But, there is human value which not yet emerged in composition of narasi student, that is human value with indicator dare to advocate truth. This matter because of some possibility, that is lack of student knowledge concerning action dare to advocate truth, or lack of done/conducted by activity is student directly regarding/ hit dare to advocate truth.

\section{Value Association}

Association value found in 33 composition article of narasi student. Assess association with indicator love fatherland found in 3 sentence found on 3 result of composition of narasi student. Assess association with indicator move forward assocciation which is Single Bhinneka of Ika found in 16 sentence found on 15 result of composition of narasi student. Assess association with 
indicator volunteer hold the bag for the sake of with found in 34 sentence found on 29 result of composition of narasi student. Assess association with indicator respect unity and association found in 13 sentence found on 10 result of composition of narasi student.

As a whole at association value found by counted 33 composition of narasi student which in it emerge 66 sentence which enter in plenty of category with percentage $29 \%$ expressing last for meaning related to association value. Following solution of analysis assess association. Composition article of narasi student with code of A1, A2, A3, A4, A5, A6, A7, A8, A9, A10, B2, B3, B4, B6, B7, B8, B9, B10, C1, C2, C3, C4, C5, C6, $\mathrm{C} 7, \mathrm{C} 8, \mathrm{C} 9, \mathrm{C} 10, \mathrm{D} 1, \mathrm{D} 3, \mathrm{D} 4, \mathrm{D} 5$, and D6 there are association value, because at sentences with the student code write down word play together without selecting friend, borrowing friend requiring and foundation life with friend with various difference. The word show or meaningful that all activity which is mentioned in composition of narasi the student relate to the effort up at coalescing as forming of to feel nationalism in Indonesia, and as form acknowledge variety or difference in Indonesia state, this matter as according to third principle of Five Principles.

This matter as according to content of[is meaning of pregnant association value of meaning of [is effort up at coalescing in circularity of people to construct to feel nationalism in Unity State Republic Of Indonesia, at the same time confess and esteem fully to variety had by Indonesian nation (Margono, 2002).

Pursuant to solution above, result of composition of narasi student concerning association value with indicator: (1) fatherland love, (2) moving forward assocciation which is Bhinneka Tunggal Ika, (3) volunteer hold the bag for the sake of with, and (4) respect unity and association, have emerged in composition of narasi student. This matter is influenced by student routinely have done/conducted activity related to is fourth of indicator. The activitys besides routine done/conducted by in possibility school is also done/conducted at home, and also in society, taking example, flag ceremony which is routine to be executed in school every day Monday, because passing this flag ceremony represent one of the form of fatherland love able to also strengthen unity and association. Besides in everyday life of student can pal up with who so ever without having to differentiate husk colour, physique, tribe, race, and also religion, the mentioned as form of is existence of attitude associate with friend's as according to our state password namely Bhinneka Tunggal Ika owning meaning different each other but remain to one also. Existence of feeling empathy to help or assist fellow being without differentiating. Hence from that from result of composition of narasi student which have been written, can be bring out is fourth of indicator of association value.

\section{Value Nationality}

Nationality value found in 13 composition article of narasi student. Assess nationality with deliberation indicator to reach general consensus in a condition of by feeling familiarity found in 13 sentence found on 13 result of composition of narasi student. Assess nationality with indicator major deliberation in taking decision for the sake of with found in 13 sentence found on 13 student article.

As a whole at nationality value found by counted 13 composition of narasi student which in it emerge 26 sentence which enter in category enough with percentage $11 \%$ expressing very less for meaning related to nationality value. Following solution of analysis assess nationality. Composition article of narasi student with code of A1, A4, A5, A7, A8, A9, B9, C1, C2, C6, C7, C9, and D6 there are nationality value, because at sentences with the student code write down word have deliberation. The word show or meaningful that democracy in everyday life is also needed is even majored for the sake of with, this matter as according to fourth principle of Five Principles.

This matter as according to content of[is meaning of nationality value namely represent value which jell to Indonesia embracing democracy culture, and constitute citizen to be able to comprehend taken by decision is leader (which initially selected collectively/together also) for prosperity together (Meinarno, 2016).

Pursuant to solution above, result of composition of narasi student concerning Nationality value with indicator: (1) deliberation to reach general consensus in a condition of by feeling familiarity, and (2) majoring deliberation in taking decision for the sake of with, have emerged in composition of narasi student. This matter is influenced by student routinely have done/conducted activity related to both indicator. The activitys besides routine done/conducted by in possibility school is also done/conducted at home, and also in society, taking example, doing/conducting deliberation before hand before determining something, for example deliberation determination of monitor, deliberation for the election of RW, and others. Through deliberation later will be got by a general consensus representing result of agreement from entire/all deliberation member, so that in determining something remain to take care of to feel familiarity well and guarantee reconciliation. Hence from that from result of composition of narasi student which have been written, can be peeped out both indicator of nationality value.

But, there is nationality value which not yet emerged in composition of narasi student, that is nationality value with indicator do not force others will; desire and sovereignty reside in on-hand people, do not be found in result of composition of narasi student. This matter because of some possibility, that is lack of student knowledge regarding/ hit do not force others will; desire and sovereignty reside in on-hand people, or lack of done/conducted by activity is student directly regarding/ hit do not force others will; desire and sovereignty reside in on-hand people.

\section{Value Justice}

Justice value found in 15 composition article of narasi student. Assess justice with indicator behave fair found in 2 sentence found on 2 result of composition of narasi student. Assess justice with indicator balance among/between rights and obligations found in 6 sentence found on 6 result of composition of narasi student. Assess justice with familiarity attitude indicator and mutual assistance found in 8 sentence found on 8 result of composition of narasi student. 
As a whole at justice value found by counted 15 composition of narasi student which in it emerge 16 sentence which enter in category a few/little with percentage $7 \%$ expressing very less for meaning related to the infinite value. Following solution of analysis assess justice. Composition article of narasi student with code of A1, A2, A4, A5, A6, A8, B2, B4, B7, C3, C7, D1, D3, $\mathrm{D} 4$, and D5 there are justice value, because at sentences with the student code write down fair word, mutual assistance and cooperation. The word show or meaningful that all activity which is mentioned in composition of narasi the student relate to the effort human being having readiness and willingness to fulfill its obligation, and behave fair as according to tempatmya, this matter as according to fifth principle of Five Principles.

This matter as according to content of [is meaning of justice value that is reaching of Prosperous and Fair Indonesia society by lahiriah and or spirituality. Assess justice is something that it is true expected by in society, and hand in glove justice value of its bearing with how feeling is fair of do not for him/her self, but for the society of individual place reside in (Meinarno, 2016).

Pursuant to solution above, result of composition of narasi student concerning justice value with indicator: (1) behaving is fair, (2) balancing among/between rights and obligations, and ( 3) familiarity attitude and mutual assistance, have emerged in composition of narasi student. This matter is influenced by student routinely have done/conducted activity related to third indicator. The activitys besides routine done/conducted by in possibility school is also done/conducted at home, and also in society, taking example, do together with citizen, routine piket in class, mess together; with, overtake and responsibility as student, and behave fairly.

But, there is justice value which not yet emerged in composition of narasi student, that is justice value with indicator always scrimp and is not extravagant, do not be found in result of composition of narasi student. This matter because of some possibility, that is lack of student knowledge concerning action always scrimp and is not extravagant, or lack of done/conducted by activity is student directly regarding/hit always scrimp and is not extravagant.

\section{CONCLUSION}

Pursuant to result of analysis and research can be concluded that at composition of narasi class student 4 SDN Pandanwangi 3 Kota Malang found by entire/all Five Principles value, that is: (1) the infinite, (2) is human, (3) association, (4) nationality, and (5) justice. Entire/All finding assess Five Principles which there are in composition of narasi the student counted 233 sentence which there are in 35 result of composition of narasi student.

Analysis assess Five Principles at composition of narasi student can be formulated as follows. Analysis assess the infinite there are 79 sentence expressing plenty of, with percentage $34 \%$ showing category enough. Analyse human value there are 46 sentence expressing many, with percentage $20 \%$ showing category enough. Analyse association value there are 66 sentence expressing plenty of, with percentage 29\% showing category enough. Analyse nationality value there are 26 sentence expressing enough, with percentage $11 \%$ showing category very less. Analysis assess justice there are 16 sentence expressing a few/little, with percentage $7 \%$ showing category very less.

\section{REFERENCES}

[1] Akbar, Sa'dun. 2013. Instrumen Perangkat Pembelajaran. Bandung: PT Remaja Rosdakarya.

[2] Arsyad, Azhar. 2014. Media Pembelajaran. Jakarta: PT Rajagrafindo Persada.

[3] Finoza, L. 2008. Komposisi Bahasa Indonesia. Jakarta: Insan Mulia.

[4] Kaelan, MS. 2014. Pendidikan Pancasila. Yogyakarta: Paradigma.

[5] Kamus Besar Bahasa Indonesia. 2008. Jakarta: PT Gramedia Pustaka Utama.

[6] Keraf, G. 2007. Argumentasi Dan Narasi Komposisi Lanjutan III. Jakarta: PT Gramedia.

[7] Komaludin, A. \& Umiyati, N. 2014. Cara Cespleng Pintar Bahasa Indonesia SD Kelas 4, 5, 6. Yogyakarta: Andi Offset.

[8] Kurniawan, H. 2013. Sastra Anak Dalam Kajian Strukturalisme, Sosiologi Semiotika, Hingga Penulisan Kreatif. Yogyakarta: Graha Ilmu.

[9] Kusumaningsih, D. 2013. Terampil Berbahasa Indonesia. Yogyakarta: CV Andi Offset.

[10] Margono. 2002. Pendidikan Pancasila. Malang: Universitas Negeri Malang (UM PRESS).

[11] Meinarno. 2016. Pembuktian Kekuatan Hubungan Antara Nilai-nilai Pancasila Dengan Kewarganegaraan. Jurnal Ilmiah Pendidikan Pancasila dan Kewarganegaraan, 1, 14-15.

[12] Moeleong, Lexy, J. 2014. Metodologi Penelitian Kualitatif Edisi Revisi. Bandung: PT Remaja Rosdakarya.

[13] Mulyati, Y. 1998. Pendidikan Bahasa \& Sastra Indonesia di Kelas Tinggi. Jakarta: Universitas Terbuka.

[14] Nawawi, I. 2016. Pendidikan Kewarganegaraan Sekolah Dasar (PKn SD). Malang: Universitas Negeri Malang.

[15] Nawawi, I. 2016. Pengembangan Pendidikan Karakter Berbasis Kantin Kejujuran di Sekolah Dasar Se- Malang Raya. Malang. Universitas Negeri Malang.

[16] Nurgiyantoro, B. 2005. Sastra Anak. Yogyakarta: UGM Press.

[17] Nurgiyantoro, B. 2007. Sastra Anak Pengantar Pemahaman Dunia Anak. Yogyakarta: Gadjah Mada University Press.

[18] Nurudin. 2010. Dasar-dasar Penulisan. Malang: UMM Press.

[19] Prastowo, A. 2012. Metode Penelitian Kualitatif dalam Perspektif Rancangan Penelitian. Jogjakarta: Arruzzmedia.

[20] Ratnapuri, R. 2018. Analisis Nilai Karakter pada Karangan Fabel Siswa Kelas IV SD di Desa Pager Lor Kecamatan Sudimoro Kabupaten Pacitan. Malang: FIP UM.

[21] Rumidjan. 2015. Dasar Keilmuan Bahasa Indonesia SD. Malang: Universitas Negeri Malang.

[22] Rumidjan. 2013. Dasar Keilmuan dan Pembelajaran Sastra Anak SD. Malang: Fakultas Ilmu Pendidikan Universitas Negeri Malang.

[23] Satori, D. \& Komariah, A. 2011. Metodologi Penelitian Kualitatif. Bandung: Penerbit Alfabeta

[24] Sehandi, Y. 2014. Mengenal 25 Teori Sastra. Yogyakarta: Andi Offset

[25] Sriana, S. 2014. Analisis Teks Bacaan dalam Buku Teks Bahasa Indonesia Ditinjau dari Pendidikan Karakter. Malang: FIP UM. 
[26] Sugiyono. 2007. Memahami Penelitian Kualitatif. Bandung: Penerbit Alfabeta.

[27] Sugiyono. 2008. Memahami Penelitian Kualitatif. Bandung: Penerbit Alfabeta.

[28] Suparno. 2008. Ketrampilan Dasar Menulis. Jakarta: Universitas Terbuka.

[29] Tobroni. 2007. Pendidikan Kewarganegaraan Demokrasi, HAM, Civil Socieety, dan Multikulturalisme. Malang: Pusat Studi Agama, Politik, dan Masyarakat (PuSaPom).

[30] Ulfatin, N. 2013. Metode Penelitian Kualitatif di Bidang Pendidikan: Teori dan Aplikasinya. Malang: Fakultas Ilmu Pendidikan Universitas Negeri Malang.

[31] Undang-undang Republik Indonesia Nomor 20 Tahun 2003 tentang Sistem Pendidikan Nasional. Retrieved 2 Juliy 2019, from http://kelembagaan.ristekdikti.go.id/wpcontent/uploads/2016/08/UU_no_20_th_2003.pdf.
[32] Wahidin. 2016. Pendidikan Kewarganegaraan. Jakarta: Media.

[33] Wardhini, R. 2018. Analisis Muatan Nilai-nilai Pancasila dalam Buku Siswa Kelas II Tema Hidup Rukun. Malang: FIP UM

[34] Winarni, R. 2014. Kajian Sastra Anak. Yogyakarta: Graha Ilmu.

[35] Winarno. 2011. Pendidikan Kewarganegaraan Panduan Kuliah di Perguruan Tinggi. Jakarta: PT Bumi Aksara.

[36] Zakky. 2018. 45 Butir-butir Pancasila Terbaru Sebagai Pedoman Pengalaman Pancasila. Retrieved 2 Juliy 2019 , from https://www.zonareferensi.com/butir-butir-pancasila.

[37] Zulela. 2013. Pembelajaran Bahasa Indonesia Apresiasi Sastra di Sekolah Dasar. Bandung: PT Remaja Rosdakarya. 